\title{
Analysis Of Risk Management In Development SMK Stikes Rajawali Bandung (Case Study: Well Foundation)
}

\author{
Firda Aulia Khairin ${ }^{1}$, Annisa $^{1}$, Ilham $^{1}$ \\ Civil Engineering, Faculty of Engineering and Design, Institut Teknologi Sains Bandung, Central Cikarang, Indonesia \\ E-mail: firdaaulia22@ gmail.com
}

Manuscript Information:

Accepted

11 January 2021

Revised

31 January 2021

Approved

14 February 2021

Published

28 February 2021

\begin{abstract}
The SMK STIKES Rajawali Bandung project is a unique project because it has a steep terrain location that creates various risks, so a risk analysis is needed. The identification in this study was 32 risks. This research uses qualitative and quantitative methods with the stages of identifying possible risks, assessing risks, knowing the causes, and ways of dealing with dominant risks if they occur. The results of the study of the 32 risks consisted of 3 very high risks, 2 high risks, 23 medium risks and 4 low risks. The biggest risk comes from the external risk that can be detected, namely the risk of rain with a score of 20. Therefore, the risk of rain requires ideal treatment using a dewatering pump.
\end{abstract}

Keywords: risk identification, assessment, mitigation

\section{INTRODUCTION}

Over time, the development of the construction industry has become increasingly diverse, complex and sophisticated. The construction consists of different stages, where the determining stage is the construction stage because the overall quality of the project depends on construction and construction management ${ }^{2}$. During the construction phase, the contractor must plan, plan, schedule, plan and control the project carefully and achieve the project objectives.

Project management is the application of 10 areas of knowledge, skills, tools and techniques in project activities to achieve project goals. Construction projects cannot be separated from three aspects, namely time, cost and implementation1). Therefore, every construction project implementation requires good project management to be able to 
manage and minimize various project risks that can occur. The success of a project is determined if at the right time, the costs do not exceed the budget, the quality meets the requirements, at least a change in the scope of work, the results can be carried out properly by the owner9).

Problems in project implementation are caused by many internal and external factors starting from the initial stages of project implementation, namely the design stage, the procurement process, implementation to handover19). This problem causes delays in project goals and objectives that have been planned. Therefore, risks must be managed properly. Risk is an uncertain condition that has a positive or negative impact on project results14). The extent to which the impact caused by these risks can be known through Project Risk Management Project risk management is the application of risk management elements, namely risk management planning, risk identification, qualitative risk analysis, quantitative risk analysis, risk response, risk response implementation and risk monitoring14). Construction project risk management must be managed adequately so that the benefits to be obtained are in accordance with the risks faced.

One of the project conditions that affect development is the project location. The project location affects the risk management of work in the field, including foundation work, structural works, finishing and complementary works5). Foundation work is the most important part of a building construction project, because foundation work is a load transmitter from the building above the structure to the soil layer below20). This study analyzes foundation risk management. Working on a case study of a 5-story building with steep and varied boundary conditions at SMK STIKES Rajawali Bandung.

The construction project of SMK STIKES Rajawali Bandung is located in West Bandung Regency and was built from January 9, 2018, to November 7, 2019. The construction of the project is built on steep terrain that creates various project risks that can hinder project progress. And it affects project achievement. One of the jobs that is hampered is foundation work, where this work is delayed. The delay in foundation work affects subsequent work items (such as structural, finishing, and additional work). Work planning started on March 2, 2018, to March 22, 2018, but when the field started on March 2, 2018, to April 12, 2018, there was a delay in the implementation time for 21 days (The initial plan was 34 days, but the implementation in the field was 55 days). Delays in implementation time due to steep ground location resulting in mobilization, weather, and lack of material storage and project control. Based on the above background, the purpose of this study is to identify risks, risk analysis and risk mitigation the construction of SMK STIKES Rajawali Bandung.

\subsection{Project Risk Management}

Risk management is generally the process of identifying, measuring, ascertaining risks and strategies, which work to create and protect value ${ }^{8)}$. The risks are viewed negatively, such as losses, dangers and other consequences ${ }^{18}$. Risk is an uncertain situation that has a 
positive or negative impact on project results and objectives ${ }^{14)}$. This risk has three main elements, namely: events, frequency, impact ${ }^{9}$.

\subsection{Risk Identification}

Risk identification is the initial stage in risk management which aims to reduce sources of risk and events that hinder the achievement of project objectives ${ }^{14)}$. Sources of risk are divided into two parts, namely external and internal causes, because the causes of risk do not have a universal standard in their distribution ${ }^{19)}$.

\subsection{Risk Assessment}

Risk analysis to measure risk based on the calculation or assessment of its frequency and impact. Risk assessments can be mapped into a risk matrix. This risk matrix shows where the risk is based on the level of risk. The risk matrix will be used at a later stage to identify existing risks. The following is a risk matrix ${ }^{16)}$

Table 1. Risk Matrix

Impact

\begin{tabular}{|c|c|c|c|c|c|c|c|}
\hline & 1 & 2 & 3 & 4 & 5 \\
\hline & & & Insignifant & Minor & Moderate & Major & Extreme \\
\hline \multirow{5}{*}{ Frequency } & \multirow{2}{*}{$\begin{array}{l}1 \\
\mathbf{2}\end{array}$} & Very unlikely & Low & Low & Low & Medium & Medium \\
\hline & & unlikely & Low & Medium & Medium & Medium & High \\
\hline & 3 & Possible & Low & Medium & Medium & High & High \\
\hline & 4 & Likely & Medium & Medium & High & High & Very High \\
\hline & 5 & Almost Certain & Medium & High & High & Very High & Very High \\
\hline
\end{tabular}

Risk level is formulated as follows:

Risk $=$ Frequency $x$ Impact

The scale used in assessing risk to frequency and impact is the likert scale ${ }^{4)}$. The Likert scale serves to provide a score in this research questionnaire. The scale of the frequency and impact can be seen in Table 2.

Table 2. Frequency Level Scale and Impact Level Scale

\begin{tabular}{ccc}
\hline Level & Frequency & Impact \\
\hline 1 & Very Low & Very Small \\
2 & Low & Small \\
3 & Moderate & Moderate \\
4 & High & Large \\
5 & Very High & Very Large \\
\hline
\end{tabular}

\subsection{Risk Acceptability}

The level of risk is a very important tool in making decisions because through risk ratings, management can determine priorities and treatments at the construction stage ${ }^{3)}$. The level of risk acceptance depends on the result of multiplying the frequency with the impact. The level of risk acceptance can be seen in Tabel 3. 
Table 3. Risk Acceptability

\begin{tabular}{cc}
\hline Assessment & Acceptance Scale \\
\hline Unacceptable & $\mathrm{x} \geq 15$ \\
Undesirable & $5 \leq \mathrm{x}<15$ \\
Acceptable & $3 \leq \mathrm{x}<5$ \\
Negligible & $\mathrm{x}<3$ \\
\hline
\end{tabular}

\subsection{Risk Mitigation}

Risk mitigation is a strategy carried out to reduce the impact of identified risks. Sometimes there are risks that cannot be eliminated, sometimes they can only be reduced so that the result is residual risks. So 4 risk management strategies are needed, namely: avoid, reduce, receive, overcome, and take a turn ${ }^{15}$.

\section{METHODS}

This research is taken from a case study in the SMK STIKES Rajawali Bandung project with qualitative and quantitative methods, which aim to make a systematic description of the risk events under study. The descriptive method used was a questionnaire and interviews that took place in the field. And aims to get opinions from respondents about events that pose risks in foundation work.

\subsection{Variables}

Based on the results of previous research assessments there are variables and risks that generally occur in construction projects which will then be used as identification for the questionnaire. From previous research there are 4 variables and 32 indicators which will be grouped in Table 4 of the following variables and indicators:.

Table 4. Variable and Indicators

\begin{tabular}{|c|c|c|c|}
\hline No. & Variable & Indicators & Reference \\
\hline 1 & $\begin{array}{l}\text { External } \\
\text { cannot be } \\
\text { detected }\end{array}$ & $\begin{array}{l}\text { - Avalanche } \\
\text { - Flood } \\
\text { - Earthquake }\end{array}$ & $\begin{array}{l}\text { Magna, et al (2017) } \\
\text { Subiyanto (2010) }\end{array}$ \\
\hline 2 & $\begin{array}{l}\text { External } \\
\text { can be } \\
\text { detected }\end{array}$ & $\begin{array}{l}\text { - Inflation or an increase in prices and a } \\
\text { decrease in purchasing power } \\
\text { - Rain } \\
\text { - Project locations that are difficult to reach }\end{array}$ & $\begin{array}{l}\text { Magna, et al (2017) } \\
\text { Subiyanto (2010) } \\
\text { Nugraheni, et al (2012) }\end{array}$ \\
\hline 3 & $\begin{array}{l}\text { Internal } \\
\text { technical }\end{array}$ & $\begin{array}{l}\text { - Inaccurate soil data } \\
\text { - Sting errors of the soil are excavated } \\
\text { - Excavation has not yet reached the } \\
\text { elevation plan } \\
\text { - Errors in determining drilling points and } \\
\text { on the foundation } \\
\text { - Non-alignment of foundation drilling } \\
\text { - The ground collapses were found around } \\
\text { the borehole }\end{array}$ & $\begin{array}{l}\text { Magna, et al (2017) } \\
\text { Subiyanto (2010) } \\
\text { Ismael, et al (2014) } \\
\text { Messah, et al. (2013) } \\
\text { Hartono (2015) }\end{array}$ \\
\hline
\end{tabular}




\begin{tabular}{|c|c|c|c|}
\hline & & $\begin{array}{l}\text { - Concrete pouring error } \\
\text { - Low labor productivity } \\
\text { - Low equipment productivity } \\
\text { - Tool damage } \\
\text { - If there is no provision of construction } \\
\text { equipment at the project site } \\
\text { - The quality and quantity of the material } \\
\text { - do not match the specifications } \\
\text { - Delays in delivery of materials to } \\
\text { locations } \\
\text { - Lack of material storage space } \\
\text { - Delay in ordering material } \\
\text { - Material fabrication failure } \\
\text { - Material breakdown } \\
\text { - There are design changes } \\
\text { - Incomplete planning (drawing) } \\
\text { - Delay in the process of requesting and } \\
\text { approving work spaces by the owner }\end{array}$ & \\
\hline 4 & $\begin{array}{l}\text { Internal } \\
\text { non } \\
\text { technical }\end{array}$ & $\begin{array}{l}\text { - Time and cost control systems are weak } \\
\text { - Late payment owner } \\
\text { - There is work that is not recognized as a } \\
\text { bill } \\
\text { - Lack of time control information to } \\
\text { monitor and analyze schedule estimation } \\
\text { errors that affect project performance } \\
\text { - Sequencing that is not good enough } \\
\text { - The other job that goes before is too late }\end{array}$ & $\begin{array}{l}\text { Magna, et al (2017) } \\
\text { Subiyanto (2010) } \\
\text { Ismael, et al (2014) } \\
\text { Messah, et al. (2013) }\end{array}$ \\
\hline
\end{tabular}

\section{RESULT AND DISCUSSION}

The results of distributing questionnaires totaled 42 respondents, consisting of $43.2 \%$ of respondents as workers, $7.14 \%$ of respondents as surveyors, logistics, $4.7 \%$ of respondents as quantity surveyors, quality control, supervisor, drafter, administration, project manager, engineering, administration, executors and $2.38 \%$ of respondents as project managers, project heads, technical heads, technical managers, operational managers, administrative managers, chief supervisors, project operational control. In this study, they had quite a long project experience, about 5 to 9 years, and the majority of respondents had a bachelor's degree of $53.36 \%$, while vocational and high school education were $40.5 \%$ and $7.14 \%$, to get an assessment of the frequency and impact of risks on work foundation in the SMK STIKES Rajawali construction project.

\subsection{Risk Analysis}

The results of the questionnaire were obtained as an analysis of risk, namely: there are 3 very high risks, 2 high risks, 23 medium risks, and 4 low risks. The biggest risk comes 
from external risk that can be detected, namely very high with a rain risk value of 20 . Risk analysis can be seen in the Table 5 .

Table 5. Risk Analiysis

\begin{tabular}{|c|c|c|c|}
\hline No. & Indicators & $\begin{array}{l}\text { Risk } \\
\text { Score }\end{array}$ & $\begin{array}{l}\text { Risk Matrix } \\
\text { Grouping }\end{array}$ \\
\hline 1 & Avalanche & 4 & Medium \\
\hline 2 & Flood & 4 & Medium \\
\hline 3 & Earthquake & 3 & Low \\
\hline 4 & $\begin{array}{l}\text { Inflation or an increase in prices and a decrease in } \\
\text { purchasing power }\end{array}$ & 15 & High \\
\hline 5 & Rain & 20 & Very High \\
\hline 6 & Project locations that are difficult to reach & 16 & Medium \\
\hline 7 & Inaccurate soil data & 4 & Low \\
\hline 8 & Sting errors of the soil are excavated & 2 & Medium \\
\hline 9 & Excavation has not yet reached the elevation plan & 4 & Medium \\
\hline 10 & Errors in determining drilling points and on the foundation & 4 & Medium \\
\hline 11 & Non-alignment of foundation drilling & 4 & Medium \\
\hline 12 & The ground collapses were found around the borehole & 5 & Medium \\
\hline 13 & Concrete pouring error & 4 & Medium \\
\hline 14 & Low labor productivity & 4 & Medium \\
\hline 15 & Low equipment productivity & 4 & Medium \\
\hline 16 & Tool damage & 4 & Medium \\
\hline 17 & $\begin{array}{l}\text { If there is no provision of construction equipment at the } \\
\text { project site }\end{array}$ & 3 & Low \\
\hline 18 & $\begin{array}{l}\text { The quality and quantity of the material do not match the } \\
\text { specifications }\end{array}$ & 4 & Medium \\
\hline 19 & Delays in delivery of materials to locations & 9 & Medium \\
\hline 20 & Lack of material storage space & 12 & High \\
\hline 21 & Delay in ordering material & 5 & Medium \\
\hline 22 & Material fabrication failure & 4 & Medium \\
\hline 23 & Material breakdow & 5 & Medium \\
\hline 24 & There are design changes & 3 & Low \\
\hline 25 & Incomplete planning (drawing) & 4 & Medium \\
\hline 26 & $\begin{array}{l}\text { Delay in the process of requesting and approving work } \\
\text { spaces by the owner }\end{array}$ & 4 & Medium \\
\hline 27 & Time and cost control systems are weak & 16 & Very High \\
\hline 28 & Late payment owner & 4 & Medium \\
\hline 29 & There is work that is not recognized as a bill & 4 & Medium \\
\hline 30 & $\begin{array}{l}\text { Lack of time control information to monitor and } \\
\text { analyze schedule estimation errors that affect project } \\
\text { performance }\end{array}$ & 4 & Medium \\
\hline 31 & Sequencing that is not good enough & 4 & Medium \\
\hline 32 & The other job that goes before is too late & 9 & Medium \\
\hline
\end{tabular}




\subsection{Risk Acceptability}

From the risk analysis there are 4 types of risk acceptance, namely: unacceptable amounting to 3 risk $(9,375 \%)$, undesirable amounting to 4 risk (12,5\%), acceptable amounting to 24 risk (75\%), and negligible amounting to 4 risk $(12,5 \%)$. The results of this study show that acceptance of risk that falls into the category requires treatment, namely unacceptable and undesirable risks.

\subsection{Risk Mitigation}

Risk mitigation that falls into the risk category is unacceptable and undesirable. Risk treatment can be seen in Table 6 .

Table 6. Risk Mitigation

\begin{tabular}{|c|c|c|c|}
\hline No. & $\begin{array}{c}\text { Risk } \\
\text { Identification }\end{array}$ & Causes of Risk & Risk Mitigation \\
\hline 1 & $\begin{array}{l}\text { Inflation or } \\
\text { an increase in } \\
\text { prices and a } \\
\text { decrease in } \\
\text { purchasing } \\
\text { power }\end{array}$ & $\begin{array}{l}\text { The increase in the price of } \\
\text { iron due to the game on the } \\
\text { market price reached } 30-50 \% \\
\text { of the estimated price or iron }\end{array}$ & $\begin{array}{l}\text { - Make an estimate of the } \\
\text { increase in raw material prices } \\
\text { - Making contracts with } \\
\text { suppliers with an umbrella } \\
\text { contract system } \\
\text { - Looking for a material supplier } \\
\text { that offers lower prices }\end{array}$ \\
\hline 2 & Rain & $\begin{array}{l}\text { The groundwater level } \\
\text { becomes high because it often } \\
\text { rains during foundation work }\end{array}$ & $\begin{array}{l}\text { - Prepare for dewatering } \\
\text { - Provide a drainage system }\end{array}$ \\
\hline 3 & $\begin{array}{l}\text { Project } \\
\text { locations that } \\
\text { are difficult } \\
\text { to reach }\end{array}$ & $\begin{array}{l}\text { When it rains, access to the } \\
\text { project entrance becomes } \\
\text { difficult for material delivery } \\
\text { to the project site }\end{array}$ & $\begin{array}{l}\text { - Prepare alternative access } \\
\text { roads to facilitate mobilization }\end{array}$ \\
\hline 4 & $\begin{array}{l}\text { Delays in } \\
\text { delivery of } \\
\text { materials to } \\
\text { locations }\end{array}$ & $\begin{array}{l}\text { The supplier did not send iron } \\
\text { material according to schedule, } \\
\text { so this project had to wait a } \\
\text { long time for iron supply }\end{array}$ & $\begin{array}{l}\text { - Make schedule, evaluate the } \\
\text { arrival and the amount of } \\
\text { material } \\
\text { - Contact the supplier to } \\
\text { negotiate the material ordered, } \\
\text { speed up immediately } \\
\text { - Speed up the work of the upper } \\
\text { structure }\end{array}$ \\
\hline 5 & $\begin{array}{l}\text { Lack of } \\
\text { material } \\
\text { storage space }\end{array}$ & $\begin{array}{l}\text { The difficulty of determining } \\
\text { the desired material due to the } \\
\text { accumulation of material in the } \\
\text { warehouse }\end{array}$ & $\begin{array}{l}\text { - Schedule delivery periodically } \\
\text { - Renting a material storage area }\end{array}$ \\
\hline 6 & $\begin{array}{l}\text { Time and } \\
\text { cost control } \\
\text { systems are } \\
\text { weak }\end{array}$ & $\begin{array}{l}\text { The foundation work was } \\
\text { delayed, so the casting was too } \\
\text { late }\end{array}$ & $\begin{array}{l}\text { - The cost and time control } \\
\text { system is kept simple but quite } \\
\text { up to date } \\
\text { - Monitoring and reviewing the } \\
\text { implementation schedule }\end{array}$ \\
\hline
\end{tabular}




\begin{tabular}{|c|c|c|c|}
\hline & & & $\begin{array}{l}\text { periodically } \\
\text { - If there is a deviation from the } \\
\text { implementation schedule, a } \\
\text { recovery is carried out which is } \\
\text { discussed in the meeting to } \\
\text { plan follow-up }\end{array}$ \\
\hline 7 & $\begin{array}{l}\text { The other job } \\
\text { that goes } \\
\text { before is too } \\
\text { late }\end{array}$ & $\begin{array}{l}\text { Rain conditions become } \\
\text { difficult when removing the } \\
\text { sludge from the foundation } \\
\text { work, so that the dump truck } \\
\text { cannot enter and exit the } \\
\text { project because it is muddy. In } \\
\text { addition, when drilling is not } \\
\text { cast immediately, the } \\
\text { foundation hole that has been } \\
\text { drilled will collapse and the } \\
\text { next work will be delayed }\end{array}$ & $\begin{array}{l}\text { - Doing project crashing } \\
\text { - Do fast tracking } \\
\text { - Cover additional time with } \\
\text { contingency time }\end{array}$ \\
\hline
\end{tabular}

Based on the risk analysis, the biggest risk in SMK Stikes Rajawali Bandung is the risk of rain. Thus, a risk handler is required for foundation work. Risk handlers for rain variables use a dewatering pump or drainage ${ }^{11)}$. The following is a comparison of alternatives to dewatering pump and drainage based on the parameters in table 7.

Table 7. Comparison of Dewatering Pump and Drainage

\begin{tabular}{|c|c|c|}
\hline Parameter & Dewatering Pump & Drainage \\
\hline Material & - & Concrete \\
\hline Tools & Electric pump and generator & Hoe and Roskam \\
\hline $\begin{array}{l}\text { Principles } \\
\text { of Action }\end{array}$ & $\begin{array}{l}\text { Ground water is pumped out, so that the } \\
\text { ground water level around the excavation } \\
\text { will flow into the pump hole by gravity, and } \\
\text { cause a decrease in the ground water level } \\
\text { around the pump area }\end{array}$ & $\begin{array}{l}\text { Flow water that comes } \\
\text { from the rain to another } \\
\text { channel to the disposal } \\
\text { place, namely a river or } \\
\text { temporary water reservoir }\end{array}$ \\
\hline Advantage & $\begin{array}{l}\text { - The groundwater level drops } \\
\text { - Improve soil stability } \\
\text { - Landslides are down } \\
\text { - Removing water in the excavation due to } \\
\text { rain }\end{array}$ & $\begin{array}{l}\text { - Land use can be } \\
\text { optimized } \\
\text { - Freeing standing water } \\
\text { in the project area due } \\
\text { to rain }\end{array}$ \\
\hline Joy & $\begin{array}{l}\text { - The surrounding land springs into down } \\
\text { - The suction of fine particles from the } \\
\text { ground by the pipe } \\
\text { - Consolidation of silt, clay or loss due to } \\
\text { increased effective stress }\end{array}$ & $\begin{array}{l}\text { - Minimizes the project } \\
\text { work area } \\
\text { - Often seen as shabby } \\
\text { and smelly }\end{array}$ \\
\hline
\end{tabular}


Based on the comparison between the two alternatives above, the ideal for handling the risk of rain at SMK STIKES Rajawali Bandung is to use a dewatering pump. This is because the dewatering pump is able to release groundwater in the foundation hole due to rain, reducing the risk of landslides due to rain, and the groundwater level decreases.

\section{CONCLUSIONS}

The results of research analysis at SMK STIKES Rajawali Project can be concluded that based on the results of the risk analysis identified 32 risks, namely: 3 very high risks, 2 high risks, 23 medium risks, and 4 low risks. The biggest risk comes from the external risk that can be detected, namely the risk of rain with a risk score of 20 . Therefore, the risk of rain requires ideal treatment using a dewatering pump. In fact, the dewatering pump is able to discharge groundwater in the foundation hole due to rain, reducing the risk of landslides due to rain and lower the groundwater table.

\section{ACKNOWLEDGMENTS}

The author would like to thank:

1. Mrs. Annisa., MT. as Supervising Lecturer I Final Project Program Civil Engineering Studies Bandung Institute of Technology and Science.

2. Mr. Ilham., MT. Supervisor II Final Project Program Civil Engineering Studies Bandung Institute of Technology and Science.

\section{REFERENCES}

1) Annisa, A. (2019). Management of Communication Project: Study Case Companies Based Engineering, Procurement, Construction and Manufacturing (EPCM) Region Industry Jababeka Cikarang. Planners Insight: Urban and Regional Planning Journal, 2 (1), 026-034.

2) Dapu, Y. C., Dundu, A. K. T., \& Walangitan, D. R. (2016). Factors That Cause Cost Overrun In Construction Projects. Journal of Civil Statics, 4(10).

3) Dharma, AAB, Putera, IGAA, \& Parami, AAD (2017). Management Risk Safety and Health Work (K3) In the Project Development Jambuluwuk Hotel \& Resort. Spectran's Journal, 5 (1), 1-87.

4) Godfrey, PS, 1996. Control of Risk, A Guide to The Systematic Management of Risk from Construction. Connstruction Industry Research and Information Association (CIRIA). Westminster London.

5) Herdianto, A., Tanjungsari, A. D. R., Hidayat, A., \& Hatmoko, J. U. D. (2015). Evaluation of Rework (Rework) on a Building Construction Project in Semarang. Journal of Civil Engineering Works, 4 (1), 93-106.

6) Hartono, Widi, etc, 2015, Risk Analysis of Upper Structure Construction Using the Analytical Hierarchy Process Method. Civil Engineering Scientific Journal, Sebelas Maret University, Surakarta. 
7) Ismael, I., \& Junaidi, J. (2014). Identification of Factors that Affect Delay Implementation of Works on Project Building in the city of Bukittinggi. Momentum Journal, 16 (1).

8) ISO Organization. (2018). ISO 31000:2018 Risk Management - Guidelines. Switzerland: ISO Organization

9) Kerzner, H. 2010. Organizing and Staffing The Project Office and Team. Project Management: A Systems Approach to Planning, Scheduling, and Controlling, 141-144.

10) Magna, MT, Hartono, W., \& Sugiyarto, S. (2017). Construction Risk Analysis of Bore Pile Structure on Projects Using the Analytical Hierarchy Process ( Ahp ) Method. Civil Engineering Matrix, 5 (2).

11) Maharani, G. R. (2011). Cost and Time Risk Management On The Under Structure Work Of A High-rise Building Project In Jakarta. Thesis.

12) Messah, YA, Widodo, T., \& Adoe, ML (2013). Study of Causes of Delays in Implementation of Building Construction Projects in Kupang City. Journal of Civil Engineering, 2 (2), 157-168.

13) Nugraheni, Vita Melia, 2012, Risk Analysis of the Non-Execusable Scope at the Implementation Stage of the Regional Station X Station Construction Project which Affects Changes in Project Performance, Thesis, Specific Project Management, Jakarta.

14) PMI. (2017). A guide to the project management body of knowledge (PMBOK) (6 th ed.). Project Management Intitute , Inc: Pennsylvania.

15) Soputan, G.E.,So,pie, B.F.,\& Mandagi, R.J. (2014).Occupational Health Health and Safety (K3) Risk Management (Case Study of the Eben Haezar High School Building Construction). Scientific Journal of Media Engineering, 4 (4).

16) Standards Australia / Standards New Zealand (AS / NZ). (2004). Handbook: Risk Management Guidelines Companion to AS / NZS 4360: 2004

17) Subiyanto, Eddy. (2010). Risk management lecture slides. Depok: University of Indonesia.

18) Suwinardi, S. (2016). Manajemen Risiko Proyek. Orbith: Majalah Ilmiah Pengembangan Rekayasa dan Sosial, 12 (3).

19) Utomo, ES, Putrad, RR, Chandra, HP, \& Kusumastuti, C. (2019). Risk Management of Wharf Repair Construction Project in Gresik City. Journalof Civil Engineering Primary Dimensions, 8(2), 115-121.

20) Wulandari, M., \& Listyawan, A. B. (2017). Behavior of Covered Square Footprints on Sand Due to Burden (Doctoral dissertation, Muhammadiyah University of Surakarta). 